One of the principles of psychosomatic medicine is that we need illness as a way of expressing our emotional feelings ... We need illness to demonstrate the fact that the universe is orderly; God does things consistently; His laws cannot be changed nor set aside because someone is 'good,' pays his tithe to the church, says his prayers, and reads his Bible.

\title{
The Need for Illness
}

$\mathbf{F}^{-1}$ OR MANY YEARS I have been interested in the subject of the need for illness. As a military chaplain on active duty for four years, and as a hospital chaplain for over nineteen years, I have often seen instances which seemed to illustrate the need for illness. It has been more difficult to see this truth in my own life, but as I have dared look at myself honestly I have had to accept the fact that I have needed every illness I ever had. I now dare assert the theory that all illness is needed, whether it is realized consciously or not. I do not state this theory lightly nor easily, but only after long and careful self-study, and study of "others." I am not able to prove this theory objectively. There have been times, especially when I have been ill, when I have revolted violently against it; there have been other times, namely when I have been relatively healthy, when I have seen it clearly.

Dr. H. Flanders Dunbar proclaimed some of this insight in her Emotions and Bodily Changes and her more popularlywritten Mind and Body and other writings. My reading of her writings has certainly had its influence on my think. ing. I have often been able to discover in myself and in other patients the close relationship between repressed emotions

\author{
MALCOLM B. BALLINGER \\ Chaplain \\ University of Michigan \\ Medical Center \\ Ann Arbor, Michigan
}

and illnesses of the mind and body. Often it has been possible to understand how certain illnesses could be "beloved symptoms," as she called them. I have seen how many of us patients have literally had our lives saved by having certain illnesses. At the time of the illness, I must admit, this idea is painful and difficult to accept, or if it is admitted, it is done so jokingly and half-heartedly. It has always been difficult, if not impossible, to see the wisdom or goodness or necessity of such a phenomenon.

For the past twelve years or so I have become closely acquainted with Dr. John M. Dorsey, a psychiatrist who was for many years chairman of the Department of Psychiatry at Wayne State University in Detroit, and lately University Professor. Through my associations with him I have gained a clearer understanding of what I had been observing. throughout the years. I have heard him say repeatedly something like this: "Socalled 'illness' or 'symptom' is the body's wonderful way of coping with some cri- 
sis. I need to appreciate this life-saving activity of my body rather than be mad or irritated at my body. Instead of trying to get rid of the symptom, or being angry at the symptom, or being angry at my body, I need to understand what is the crisis which confronts my body, and appreciate and assist its wonderful life-saving activity, knowing the body is not rational, but automatic and instinctual." He has gone on to say this is true not only of physical symptoms, but likewise true of mental symptoms, such as depression, or spiritual symptoms, such as guilt feelings. He affirms these symptoms are not to be regarded as bad, or harmful, or a sign that something terrible and chaotic has happened, but are to be accepted and appreciated as good, as life-saving, as a demonstration of the rightness and orderliness of the universe.

Recently I read a similar statement by a British psychotherapist, Dr. Harry Guntrip, who wrote in his Psychotherapy and Religion (pp. 33, 34): "The optimistic ideal of the progress of physical medicine and the discovery of more and more wonderful drugs, til all physical illness is mastered, is something of a phantasy. The fact is that the more prog. ress physical medicine has made, the more psychological illness has been unmasked and forced to the front. . . . Often, therefore, it is not simply the question of getting rid of bodily illness per se, but of whether you can give the patient something better to put in its place, either as a defence against, or more radically, to bring about a reduction of, mental pain."

In this article I am going to set forth some arguments or illustrations for the need for illness. Only one of these eight is really needed, for it includes all the others, but I know how difficult it is to understand or accept this one that is allinclusive. I am going to start with illus- trations which are readily understood. I am not necessarily expressing any one else's ideas; I accept full responsibility for whatever I shall set forth.

\section{Violation of Laws of Health.}

We are inclined as human beings to try to escape personal responsibility. We want to place the blame on something or somebody else. When responsibility begins to come close to home, and it looks as if we are personally responsible, we may begin to be defensive, blind, deaf, and unconscious, because we don't want to hear, see, nor admit blame. It is obvious to most of us that sickness or illness can result from violation of laws of health. There are not only physical laws of health, but there are mental, emotional, and spiritual laws of health that are just as absolute. None of these laws can be broken. If a law is a law, it cannot be broken; it can only be demonstrated. I may say, mistakenly: "I broke a law." I didn't break a law; if I did, it wasn't a law. We try to break laws; we try to violate them because we don't like them, or we don't understand them, or they conflict with our desires, so we are against them. Actually, we live in an orderly universe which is dependable and predictable. The universe is not chaotic. Everything that happens in our universe happens by cause and effect. There is really nothing accidental or confusing or that goes wrong. The universe never gets out of shape or out of order. I realize sometimes we like to think something went wrong, but nothing ever really does. I may become confused; I may not like what is happening; I may wish things were otherwise than they are; but anything and everything that happens, happens because it needed to happen that way because God ordained that things happen that way according to His laws. God cannot 
change His laws, else the whole universe would be thrown into confusion and chaos.

For example, the law of gravity cannot be changed or broken. Just because we might get into trouble with the law of gravity doesn't mean that we can get God to change it. Just because one likes to drink alcoholic beverages to excess doesn't mean one can escape the consequences of over-indulgence. Medical men are beginning to affirm the relationship of cigarette smoking to the incidence of lung cancer. A person might say: "I didn't know smoking might cause cancer," but this does not mean ignorance will be an excuse or defense. How many unloaded guns kill! "I didn't know the gun was loaded" did not keep the gun from firing when the trigger was pulled. A person may get angry and develop high blood pressure, and say: "I didn't know getting angry could result in high blood pressure." A person cannot expect to raise hell all his life and live in heaven in his old age! Older people are often crippled and miserable because they did not take care of their health in their younger days.

Illness is needed to demonstrate the fact that the universe is orderly; God does things consistently and in an orderly manner; He never changes; His laws cannot be changed nor set aside because someone is a "good guy," pays his tithe to the church, says his prayers, and reads his Bible. Clergymen may get the idea they have special privileges since they are ordained to do God's work, but we have clergymen who are patients in general and mental hospitals; the law applies regardless, even though a bishop pats them on the head. God does not set aside His laws for the private benefit of anyone. We need illness to remind us of this truth.
2. Defense Against Infection, Virus, Injury, Trauma, Phenomena of the Physical Universe.

We learn in medicine of the "wisdom of the body"--the body's natural ability to defend itself against viruses, bacteria, injury, etc. Illness is the way the body has of taking care of these threats. For example, the body may have its temperature elevated in order to destroy certain infections or germs which cannot live in high temperature; the body may bring about certain chemical reactions to cope with certain situations. Wounds tend to heal, and the body tends to compensate for organic defects. It has been estimated that there may be as many as one thousand bodily functions which are kept in equilibrium simultaneously both within and with others. This principle of homeostasis is also applicable at the mental and emotional level. The proper use of medicines is to assist the body as it copes with something that is threatening. Illness gives the body a chance to take care of itself. Many times all that is needed is for the person to go to bed or rest so the body can take care of the situation by itself. $A$ heart attack may slow down a person so that his body is allowed a much needed rest. Becoming unconscious or "passing out" or fainting during a frightening experience may protect the person against comprehending something which was intolerable to his consciousness and might have scared him to death. Often. times illnesses are working for our health and we should not fight nor oppose them but realize what service the illnesses are performing. The late Russell L. Dicks quoted a physician saying: "If the doctor can avoid killing his patients through drugs, most of them will get well,"-because God is working on their behalf through his own healing force. (20th Century Encyclopedia of 
Religious Ḱnowledge: "Ministering to the Sick.")

\section{Punishment for Sins Committed}

Illness as punishment for sins committed is a controversial idea. Even though you or I might not believe that God definitely, deliberately, and particularly sends illness for a particular sin as divine intervention in a person's life, many persons nevertheless do believe this. Any hospital chaplain can testify that this concept is very real to many patients. Patients tell me the sins they have committed for which they believe they are being punished by God, and will affirm they cannot possibly get well until they have atoned for their sins. They believe surgery and medicine will do no good until then.

A chaplain cannot convince patients this is not true. Carroll A. Wise tells ("Ministry to the Physically Ill" in "Journal of Clinical Pastoral Work," Vol. I, No. I, Autumn 1947) of a patient who said to her pastor: "Perhaps your God doesn't punish you for sins by sending you illness, but my God does. You worship your God, and I'll worship mine!" So perhaps we are wrong and our patients are right, and we should correct our theology to conform to the truth as many of our patients see it!

In the time of Job in the Old Testament there was a belief such as this. Bildad, Eliphaz, Zophar, and Elihu all told Job, in effect: "The reason you are sick is that you have sinned. If you want to get well, you will have to get back on the right track." Job, you remember, was described as a perfect man, "blameless and upright, who feared God, and turned away from evil." Yet these four friends who came to minister to him were thoroughly convinced of the theory that if one is ill, he needs to be ill because God is angry and is punishing the person for some sin. The people in the time of Jesus still believed this. His disciples believed the blind man brought to Him for healing must have sinned. They asked Him: "Whose sin caused this man to be born blind?" Because Jesus rejected this idea and set about to restore his sight, opposition mounted. Today I find the same opposition expressed to me by some of my patients if I try to refute this belief. Many patients will not tolerate a cure that is too easy or too quick; they often feel a need to suffer sufficiently to atone for their sins.

\section{Illness Alerts to an Undesirable Condition.}

When an illness is painful, one is clerted to the fact one ought to do something about a situation. If one puts his hand on a hot stove, he normally is alerted to the fact there is danger and he quickly jerks back his hand. If he did not have the ability to feel hotne:s, he would leave his hand on the stove and sustain a severe burn. Patients who are paraplegics or quadraplegics and cannot sense pain are in constant dan. ger. They may not sense a pressure sore or decubitus ulcer developing, for example. We should be thankful we have pain to alert us to danger. We need pain to get our attention. Many persons will not go to the doctor or to the hospital until they become so uncomfortable and miserable that they cannot work or get about any more. Any hospital chaplain has heard the story many times: the patient put off medical attention as long as he could; finally when the pain became unbearable he gave in, but found he had waited too long and was beyond medical help. Such persons need illness or pain if they are to survive. If there is no pain, or if the pain is not heeded or respected, cancer (for example) can metasticize so that surgery or radiation 
or chemotherapy is not successful.

There is also mental or emotional pain which tries to get our attention. Depression ought to be recognized as a helpful attempt of the mind or emotions to help us. Perhaps the depression is warning the person that he needs to change the nature of his relationship with others. A late bishop of my church published a little Prayer Book which contained a "Prayer for Holy Hatred." I do not know that he thought of hatred as good, but I can see it as holy and precious, for it can alert one that something has happened in his interpersonal relationships which needs correction. Jesus suggested that if you remember your brother has something against you, go be reconciled to your brother, make friends quickly, lest you get into more serious trouble. If tension, anxiety, hatred are ignored or denied or merely medicated without an investigation into the cause, a complete breakdown may result.

\section{Illness as a Way of Expressing or Discharging Emotional Feelings.}

A principle of psychosomatic medicine is: we need illness as a way of expressing our emotional feelings. If one does not express emotional feelings adequately and properly, one's body will try. Every organ of the body can express emotions. If one forces organs of the body to perform such functions to an abnormal degree, these organs are in danger of becoming overtaxed and breaking down because of the misuse. We need to learn something about our emotions and the necessity of expressing them properly.

I recall one occasion in my own life when I became extremely angry, but denied to myself the awareness of the emotion. I had the mistaken idea a clergyman was not supposed to get an- gry; since I was a clergyman, then of course I was not angry! I pretended I loved rather than $I$ hated. As a result of my denial of my true emotion, various organs of my body were forced to express it. My blood pressure increased; I developed hay fever; my anxiety increased; my efficiency in my work decreased; I seriously contemplated leaving the ministry for some other vocation. My life was in danger. My bodily symptoms and my mental anguish were trying to express my real feelings, but I refused to listen. It was not until I recognized my true emotions and began to express them outwardly and directly and truthfully, rather than inwardly and through my bodily organs, that my physical and mental health was restored. Until I gained this insight I needed my body to express my emotions for me. I could indulge in this mental mechanism tem. porarily in safety until I regained my self-consciousness, but continued or unlimited misuse could have caused irreparable injury.

Certain illnesses are quite often manifestations of emotional problems. Some specialists in psychosomatic medicine identify certain emotions with particular organ sicknesses, while others insist there is danger in stereotyping the symptomatology. But it is fairly evident that it is poor medical practice to treat the symptom without investigating the cause. For example, suppose a person is crying considerably. He goes to the doctor and complains that something is wrong with his eyes. The doctor might examine the eyes and observe tears pouring from the tear ducts. He is not likely to say: "We had better remove the tear ducts." No, for there is probably nothing wrong with the tear ducts, for they were made to produce tears. The problem is perhaps bereavement. The person needs to take care of his bereavement problem, and the tear ducts 
will take care of themselves. If pastors do not do adequate "grief work" with those who are in bereavement, it is to be expected that those persons will make their way to the doctor's office or to the hospital with physical symptoms. Dr. Erich Lindemann, formerly of Massachusetts General Hospital, and many others have carefully documented this. It has been reported by others that at least fifty per cent of all patients in a general hospital may be there as a result of serious bereavement problems that have not been resolved adequately. These illnesses are needed to help these persons discharge or express their emotional feelings of bereavement in such fashion until the ego is able to take over and handle them more adequately. The emotional feelings may be over-powering for the present; bodily symptoms may take over and keep intolerable feelings from consciousness for the moment, thus keeping the person alive.

\section{The Avoidance or Escape from} Difficult, Unwanted, or Misunderstood Life Situations.

This need for illness may be more difficult to understand or accept in oneself. We might see that "other" persons might want to avoid or escape certain things, but we find it difficult to admit it in ourselves. We talk about the headache which we have as an alibi for not going to some boring meeting. We can see that such an illness would be helpful in avoiding unwanted life situations. It is a helpful defense: "If I am sick, how can I be expected to perform, or to succeed?" It becomes a welcomed alibi. It is in danger of becoming chronic and handicapping, however.

In a staff conference, a nine-year-old boy with a colostomy was presented. This youngster had never gone to school. He had not learned to read. He had not developed much physically, mentally, nor emotionally. $\mathrm{He}$ was the youngest of the family. He was needed as a baby to be cared for, since there would not be any more babies. The members of the family needed him to be helpless so they could be needed and helpful. He needed to be ill, for as long as he was ill he received much affection, attention, and many gifts. He sensed that if he grew up he would lose his privileged position. There was no motivation to get well.

A young lady in our hospital spent much of her life as a patient because she had Hirschsprung's Disease, which is a congenital idiopathic dilation of the colon. Her colostomy assisted her to live a more normal life than otherwise would have been possible. When she became eighteen years old it was determined that surgical operation could give her a new colon and she would no longer need the colostomy. The surgical procedure was performed and was successful. Now she was "normal." But to the patient to be normal was "to have a colostomy," for she had always had one as long as she could remember. Now she refused to eat or talk; she turned her face to the wall and prepared to die. It was necessary to give her back her colostomy. With her colostomy she perked up, recovered, and later married and now has children of her own. There are people like this who have had illness so long they have to have their illness to be themselves. If some people could be cured of their illnesses, they wouldn't know how to live, so would die.

\section{Illness May Permit God (or Nature) an Opportunity to Bring About a Recuperation or Reevaluation of the Situation.}

Some persons will not take things 
seriously until they get sick. We hear patients say that they have had more time to think since being in the hospital, and now they see things in a different perspective. They say they have learned their lesson. They claim when they get home again they will start living differently. We know, however, that most of them will not do this. In desperation they are promising, as though they were saying: "God, if you will please save me this time, I promise never to do wrong again." This is often bargaining with God. It is often panic. But sometimes it is genuine insight. I remember a woman who had a terminal illiness. She was thankful for the illness because it had brought her into a relationship with God which she had never enjoyed before. She had not known God before her illness; now she had learned to value a friendship and relationship with Him. She had begun to pray, read the Bible, have better relationships with members of her family, and for the first time meaning had come to her life. She expressed thankfulness for the illness. Even though her illness was killing her body, it had restored her soul. For this woman illness was not something bad, but gave her an opportunity to become a new creature. Every illness can be used in this way. One of the opportunities of hospital chaplains is this one of helping persons use illness for their gain rather than letting it hurt them.

Dr. Viktor Frankl, a thorough and disciplined psychiatrist of Vienna, was a survivor of Nazi death camps and a founder of existential analysis. He has written of his experiences in The Doctor and the Soul and From Death Camp to Existentialism. He affirms that life involves suffering, and if life is meaningful, there must also be meaning in suffering, under any and all conditions. Frankl testifies to the sustaining power of faith in a personal, living God. He asserts it is not what happens to a person, but the attitude taken toward what happens that makes the difference. $\mathrm{He}$ is alive today because of the wholesome attitude he maintained during his harrowing experiences. He says: "A single moment can retroactively flood an entire life with meaning." (p. 49, The Doctor and the Soul.)

From these examples, we are moved to declare that illness, even a fatal illness, can become a life-saving experience. Paul Tillich suggested that "the disease of many churches, denominations and congregations is that they try to escape disease by cutting off what can produce disease, and what also can produce greatness of life. A church that has ceased to risk sickness and even demonic influences has little power to heal and to cast out demons." (The Eternal Now, p. 62.) Perhaps if we do not fight illness, but welcome and use it as a good experience sent by God for a purpose, it may become the most glorious event of one's entire life, filling all that has gone before and what is to come with meaning and significance.

\section{God Needs Our Illness to Handle Our Creatureliness.}

This need for illness is the most important one of all, for it subsumes all the others. It is the most difficult one to understand and accept, for most persons want a dualism: "good vs. bad." To say: "There is no evil, but all is good," is exciting and threatening. Clergymen tend to say: "What is the use of having clergymen if everything is good?" Physicians say: "Why do we need physicians if all illness is good?" All seem to need badness or evil to blame for things not liked or not understood or not valued.

Illness is seen as one of the ways in which God handles our creatureli. 
ness. We are not immortals, but mortals; we are not creators, but creatures; we are not divinity, but humanity. This is part of our being and a condition of our existence. It is necessary to accept this about my existence, and to call it good. It may not be understood why it should be this way, and it may be wished it were different, and it might be considered unfortunate or too bad that man is limited in this way. However, it is better not to allow oneself to feel this way any more often or longer than necessary. One should insist that all that exists is good. I exist, therefore I am good. My failure to understand something does not make it bad. My human limitations do not allow me to see or understand all about human existence, but just because $I$ do not see all of it, nor understand it, does not make it bad. I believe God sees all His creation as a whole, and sees it is good; man sees but a part of creation, and may call it bad.

Just because I do not understand why I have illness, nor understand all the phases of illness, does not make it bad or wrong or not needed. I have faith that God knows what $\mathrm{He}$ is doing, and whatever $\mathrm{He}$ does is good and needed. Nothing that God does or allows is bad. If God causes or allows man to have illness, then He needs it that way. $I$ do not know why. I can understand some of the reasons why illness can be good and needed, but I cannot see all of the reasons. By faith, however, I believe and accept.

Most patients who have illness cannot see the need for it. Nor can families of patients who have an incurable illness understand the need for it. If I were to have cancer, for example, I am sure I would have difficulty accepting it as good and needed. But I am convinced I would work hard at trying to see it as good and needed. I would not be con- tent to reject it any longer than absolutely necessary. To project the blame outside me and outside God would be a less healthy way of handling my illness than to accept it as a necessary part of my creatureliness and as a necessary part of God. I would work hard to overcome my seeing it as evil or the work of some devil, and would try not to fight it, nor oppose it, nor get angry at it. I would remind myself that I believe I live in a universe that is orderly, consistent, dependable, and good, and created by and controlled by a God who is orderly, consistent, dependable, and good. I would work very hard at developing an attitude of accepting, using, and appreciating illness rather than allowing myself to sink into an attitude of rejection, hatred, and defeat. I would not deny the existence of the illness, but would call it good and set about trying to use it. I would remember that Jesus by $H$ is attitude of accepting Himself and God was able to change a bad Friday into a Good Friday which benefitted not only Himself but the entire world. Perhaps, in some small but significant way, I could use $m y$ illness as a benefit not only to me but to others.

If tomorrow a cure for all known illnesses could be found, probably other illnesses would be invented that couldn't be cured. We have to have illness as long as we are creatures. We would not necessarily be better off without incurable illnesses. Unless we could find out why illness is needed and what purpose it serves, we would not be any better. Some researchers believe there may be found a relationship between emotional or spiritual disturbances and illness. This theory motivates much less exploration than the theory that illness is purely organic in origin. Scientific research may find cures for all known illnesses only to find the existence of 
other unknown illnesses. We might consider the possibility that as long as we are human beings, we will always have a need for some kind of illness.

\section{Bibliography}

Cabot, Richard D. and Dicks, Russell L., The Art of Ministering to the Sick, N. Y.: Macmillan, 1936

Cannon, Walter B., The Wisdom of the Body, N. Y.: Norton, 1939

Dorsey, John M., Living Consciously, Detroit: Wayne State Univ. Press, 1959

Dorsey, John M., Illness or Allness, Detroit: Wayne State Univ. Press, 1965

Dumbar, H. Flanders, Emotions and Bodily

Changes, N. Y.: Columbia Univ. Press, 1938

Dunbar, H. Flanders, Mind and Body, N. Y.: Random House, 1947
Frankl, Viktor, The Doctor and the Soul, N. Y.: Alfred A. Knopf, 1957

Frankl, Viktor, From Death Camp to Existentialism, Boston: Beacon, 1959

Guntrip, Harry, Psychotherapy and Religion, N. Y.: Harper \& Bros., 1957

Hiltner, Seward, Religion and Health, N. Y.: The Macmillan Co., 1943

Horney, Karen, The Neurotic Personality of Our Time, N. Y.: Norton, 1937

Inglis, Brian, Emotional Stress and Your Health, N. Y.: Collier Books, 1962

Robinson, G. Canby, The Patient as a Person, N. Y.: The Commonwealth Fund, 1939

Tillich, Paul, The Eternal Now, N. Y.: Charles Scribner's Sons, 1963

Tournier, Paul, The Healing of Persons, N. Y.: Harper \& Row, 1965

Winter, J. A., Origins of Illness and Anxiety, N. Y.: Julian Press, 1962

Wise, Carroll A., Religion in Illness and Health, N. Y.: Harper \& Bros., 1942

C AN your pastor help you on personal and family problems as well as on religious ones, if and when you have them? ... The basic answer to this question is 'Yes.' . . Most ministers are better general practitioners than they realize. Their failure to claim recognition as trained counselors may indicate a properly humble acknowledgment of the difficulties in this area, and is likely to mean that they are genuinely ready to listen to you. If you have some problem that is eating you, of course it will be natural for you, having told a bit of your story, to ask, 'What do you think I should do?' The sensitive pastor, aware of the complexities, may very well reply, 'I do see it's difficult, but I don't believe I know what you should do.' He ought to go on with you and consider it further. But his disclaimer of being the 'answer man' should be taken as a mark of competence. The pastor who is not at all sure what you should do ought, however, to be able to help you clarify the forces within you that are pulling you to do this or that. This clarified perspective may prove more important than any bit of action taken alone and of itself. When should you seek your pastor's help? Under what conditions is it insufficient for you to analyze your problem for yourself, discuss it within your family, or go over it with a friend? Certainly you will do such things first. These are the 'natural therapies' of life, without which we should all have to seek professional help most of the time. But when they prove insufficient, and the problem goes on rolling, then consider consulting your pastor.-From "When Can Your Pastor Help You?" by Seward Hiltwer, in "Presbyterian Life," Jan. 15, 1965 